\title{
Adolescent Vandalism: the Role of the Parent-Child Relationship in the Development of Destructive Behavior
}

\author{
Olga V. Kruzhkova ${ }^{\mathrm{a}, \star}$, Irina V. Vorobyeva ${ }^{\mathrm{a}}$, \\ Natal'ja E. Zhdanova ${ }^{c}$, Anastasia O. Ljovkina ${ }^{\mathrm{b}, \star}$ \\ ${ }^{a}$ Ural State Pedagogical University, Ekaterinburg, Russia \\ b Tyumen State University, Tyumen, Russia \\ ${ }^{c}$ Russian State Vocational Pedagogical University, Yekaterinburg, Russia \\ *Corresponding authors. E-mail: galiat1@yandex.ru, anastasia@orgpsiholog.com
}

Background. While the phenomena of intentional destroying and damaging of private property have been known since ancient times, the term "vandalism" appears only in $19^{\text {th }}$ century. In the $20^{\text {th }}$ century, much research devoted to vandalism was conducted in the spheres of criminology, sociology, psychology, and education. Nevertheless, little attention has been paid to investigating the correlation between a child's propensity for vandalism and the child-parent relationship.

Objective and Method. The main purpose of our research was to investigate the correlation between the styles of family upbringing and adolescents' propensity for vandalism. For this purpose, we analyzed the main predictors of adolescents' propensity for vandalism on the basis of the psychological diagnostics of 60 Russian families from Ekaterinburg. We investigated whether the fact that a child was brought up in a one-parent or disadvantaged family is significant for forming an adolescent propensity for vandalism. We also clarified the influence of various styles of family upbringing on an adolescent's propensity for vandalism of different types.

Results. Based on statistical analysis, we concluded that an atmosphere of violence within the family plays a key role in forming adolescents' propensity for vandalism. The style of maternal upbringing has a greater influence on determining adolescent destructive behavior than the paternal, especially when the father's parenting style is "non-interference."

Conclusion. Based on our research results, we suggest that preventive efforts against vandalism should be directed toward the prevention of family violence, and that there should be a differential approach toward parental education directed toward correcting individual parental styles of upbringing.

Keywords: vandalism, deviations in juvenile behavior, adolescence, child-parent relationships, styles of parental upbringing, destructive behavior. 


\section{Introduction}

Vandalism as a current social problem. Vandalism is widespread in modern society, but the problem of evaluating and preventing it is very complex. As a rule, society does not pay much attention to the significant losses and negative social effects of vandalism, and therefore does not have much interest in revealing its causes and predictors. Yet vandalism results not only in direct losses, but also in negative psychological effects on all members of society due to living in an environment damaged by vandalism. First, such an environment increases the stress level and decreases subjective social prosperity. (Ellaway, 2009). Second, this destruction has the viral effect of creating and spreading the impulse to imitate such action, especially among adolescents. Thirdly, objects damaged by vandals provoke further destructive acts, not only toward the environment, but also toward oneself and others (Wilson, 2013).

In the USA in 2013, more than 160 thousand people were arrested on the charge of vandalism, including more than 37 thousand adolescents (Uniform Crime Report, 2013). More than 16,000 cases of vandalism have been registered at the Moscow railway over the first nine months of $2016^{1}$. Regardless of its motivation, vandalism causes great damage and financial losses all over the world. Just one of the five Australian railway service companies reported spending about three million Australian dollars on removing graffiti from its rolling stock, and two million on reconstruction of other objects damaged by vandalism (Parliament of New South Wales Legislative Assembly, 2009, p. 4440). Great Britain’s Network Rail spends 3.5 million pounds sterling annually on repairing damage from vandalism (Networkrail. Graffiti, 2017). In Saint Petersburg in 2014, losses caused by vandals in suburban trains were over 25 million rubles.

Most of the researchers investigating vandalism concur that such destructive behavior is most common during adolescence (Elliott, 1988; Le Blanc, \& Freshette, 1989; Mawby, 2001; Vatova, 2007). It often accompanies adolescents' aggressiveness, alcoholization (Virtanen, Nummi, Lintonen, Westerlund, Hägglöf, \& Hammarström, 2015), cruel treatment of animals (Lucia \& Killas, 2017), and other deviant behavior.

One of the most important social risks of vandalism is that this model of deviant, substandard, and even illegal adolescent behavior often takes on more severe forms, and can be combined with more dangerous crimes (Agapov \& Malkov, 2006). Sporadic acts of vandalism, especially a teen's first and isolated ones, usually happen as a reaction to certain situational factors. But if a single act of vandalism is left anonymous and unpunished, it often is followed by further acts of vandalism (Levy-Leboyer, 1984). Therefore, understanding the mechanisms behind the development of adolescent destructive activity is a basic scientific problem which should be solved, so that we can suggest effective measures for preventing such behavior.

Adolescent vandalism: the role of the family environment in developing destructive adolescent behavior. The roots of adolescents' destructive behavior can be found in their family upbringing. Researchers investigating factors of deviant

1 See video news 17.09.2016 21:15, URL: http://www.m24.ru/m/videos/124265. 
and aggressive adolescent behavior often note family upbringing as a dominant contributor (Garbarino, Sebes, \& Schellenbach, 1984; De Haan, Prinzie, \& Deković, 2012; Gracia, 2015; Vorobyeva, Kruzhkova, \& Krivoshchekova, 2015). Parent-child relationships become a model and a means of building relationships between the child's personality and environment (Bogdanova \& Igoshina, 2011). They define the child's sense of himself in the space of social relationships between the poles of activeness and passiveness; openness and emotional withdrawal; empathy and indifference; and personal values and norms (Avdulova, 2013). Malfunctions in upbringing, and general disharmony and inconsistency in the family's upbringing style, can lead to children's permanent adoption of deviant forms of behavior (Simonova, 2010).

Parental rejection of their children, and the absence of parental love, warmth, and bonding with their children, are often reasons for children's mental problems (Rohner, 1984). Conflicts and physical punishment correlate with children's deviant behavior (Csémy, Hrachovinová, Čáp, \& Starostová, 2014). Some empirical Russian research also shows a stable correlation between children's deviant behavior and a hostile family atmosphere: aggressiveness, regular conflicts, and excessive strictness (Kuznecova, 2013; Koreneva, 2004).

Nevertheless, the issue of family determination of a child's vandalism remains uninvestigated. For a deeper understanding of the fundamental reasons for adolescent vandalism, we proposed to investigate the correlation between styles of family upbringing, and adolescents' propensity for vandalism. In accordance with this purpose, we set the following objectives:

- To define whether the fact that a child is brought up in a one-parent or disadvantaged family is significant for forming adolescent readiness for vandalism.

- To clarify the influence of various styles of family upbringing on adolescent readiness to participate in vandalism of different types.

- To find out whether there is a difference between maternal and paternal upbringing influences on adolescents' propensity for vandalism.

- To answer the question of whether maternal and paternal upbringing efforts are coherent with their adolescents' perception of them.

\section{Research procedure and methods}

We used a general sampling method, psycho-diagnostic tools, and further statistical data analysis: clustering, MANOVA, and linear regression.

\section{Characteristics of the sample}

60 families with at least one adolescent per family participated in this research. Respondents were:

- $\quad$ adolescents aged 11-15 (total quantity $=60 . \mathrm{M}_{\mathrm{age}}=13.00 ; \mathrm{SD}_{\text {age }}=1.50$ );

- $\quad$ mothers aged 29-50 (total quantity $=60 . \mathrm{M}_{\text {age }}=36.63 ; \mathrm{SD}_{\text {age }}=4.74$ ),

- fathers aged 35-58 (total quantity $=25 . \mathrm{M}_{\text {age }}=40.68 ; \mathrm{SD}_{\text {age }}=5.41$ ). 
We categorized families according to two objective criteria:

1. Number of parents: two-parent family or one-parent family. In our research sample, a two-parent family consisted of a biological mother and a biological father who are married.

2. Family wellbeing: disadvantaged families (registered with social and other special services due to the deviant behavior of family members) or wellto-do families (not registered with any social services). We applied family wellbeing criteria according to the definition of a disadvantaged family in Russian federal law, viz.: "Disadvantaged families are families with children who find themselves in a socially dangerous situation or families in which parents or custodians do not execute their duties of upbringing, fostering, care of children, have a negative influence on their behavior or treat them violently" [Federal law, 1999].

\section{Procedure and methods of the study}

1. Intergroup statistical analysis.

First, we investigated the adjacency between the number of parents, the family's social wellbeing, and the adolescents' propensity for vandalism using adjacency matrix and cluster analysis.

2. Psychological diagnostics.

With the help of the questionnaire "The analysis of family relationships" (Eydemiller \& Yustitskis, 1990) we diagnosed abnormalities in the upbringing process, as well as the parents' personal problems. The survey consisted of 130 statements, developed in binary form, with 20 subscales. Eleven subscales measured problems in parental upbringing style: hyperprotection; hypoprotection; indulgence or ignorance of the child's needs; excessive or insufficient duties for the child; demands on the child and prohibitions; strictness or minimality of sanctions (punishments) for misconduct; and an inconsistent style of family upbringing. Nine subscales defined the parents' personal problems: transfer of the parental feelings (one spouse toward another) onto a child; preference for childish traits in the adolescent; lack of parental confidence in the upbringing process; fear of losing the child; undeveloped parental feelings; projection of the parent's own objectionable traits onto the child; transferring conflicts between parents into the sphere of the child's upbringing; and the preference for masculine or feminine traits. Cronbach's alpha reliability coefficient for the subscales ranged from 0.7 to 0.89 (Eydemiller E.G. \& Yustitskis V.V., 1990).

We used the questionnaire 'Parental behavior and adolescents' attitude to parents" (Vasserman, Gor'kovaja, \& Romicyna, 2001) to investigate parental psychological sets, behavior, and methods of parental upbringing from the adolescent's point of view. This diagnostic tool allows one to describe child-parent relationships according to their most general characteristics: benevolence, hostility, autonomy, authoritarianism, and inconsistency. This questionnaire is based on a configurational analysis of children's reports of parental behavior called Schaefer's method (1965), which was adapted by Russian scientists at the Behterev Institute's laboratory of clinical psychology ( Wasserman, Gorkova, \& Romitzina), and was further 
used under the title ADOR ("Adolescents about parents") (Vasserman, Gor'kovaja \& Romicyna, 2000).

The application of both questionnaires provided a complex evaluation of the family upbringing process from the standpoints of both the parents and the children. Adolescents are active partners in the upbringing process, as they have their own ideas about their parents, their relationships with them, and the upbringing efforts used by parents, which can be different from the parents' ideas. The necessity for such a "cross" estimation was noted by Svedkovskaya and Archakova (Shvedovskaya \& Archakova, 2015), Gracia (Gracia, Lila \& Musitu, 2005) and many others in the context of investigating children's behavior. Children's subjective estimation of parental style of upbringing tends to differ most strongly from their parents' estimation in the pubertal period, when adolescents actively oppose themselves to the adult world.

The questionnaire "Motives of vandal behavior," developed by I.V. Vorobyeva, O.V. Kruzhkova, and S.A. Ostrikova (Vorobyeva \& Kruzhkova, 2015), was used for diagnosing the adolescents' and juniors' propensity for vandalism by considering the motivational basis for their destructive behavior. The questionnaire consisted of 80 statements describing different acts of vandalism and their motives. The extent of agreement or disagreement with these statements was scored with a 4-point scale. The method diagnosed 10 forms of vandalism: grabbing another's property (for one's own profits, possessions); aggressive (answering an offense or insult); tactical (meaning as a means to some other aims); being curious (excessively curious, destructive experimenting with the purpose of investigation); aesthetic (to change and better the environment according to one's own ideals); existential (for self-affirmation through using one's own abilities to influence society and attract social attention); protesting (opposing social and cultural norms of the adult world); conforming (being pushed by a group, necessity, or a wish to imitate the behavior of other group members); provoked by environmental discomfort (initiated by some discomfort and wish to change environment for personal needs, make it more comfortable); and provoked by boredom (searching for new experiences, and the rush connected with danger or defiance of societal bans). Cronbach's alpha reliability coefficient for the subscales ranged from 0.7 to 0.79 (Vorobyeva \& Kruzhkova, 2011).

\section{Statistical analysis}

Statistical processing of the data was done with the professional software IBM SPSS Statistics V.19. The choice of statistical methods was defined by the logic of our research.

First, we made a multivariate analysis of variance (MANOVA) for clarifying correlations between motives for adolescent vandalism and family type, as classified by the number of parents and their social wellbeing.

Then, we did a linear regression analysis in order to determine the predictors of adolescent vandalism depending on the maternal and paternal styles of parental upbringing, and the adolescents' own attitude toward this upbringing style. We used the total score of the adolescents' propensity for vandalism as a dependent variable because it reflects adolescents' general propensity for this type of destructive rela- 
tionship with the environment. Such characteristics as style of family upbringing (maternal and paternal), and adolescent perception of the family upbringing, were considered as independent variables. We analyzed regression models in each separate group of families (one-parent well-to-do families, one-parent disadvantaged families, two-parent well-to-do families, and two-parent disadvantaged families). We got the final regression models using the method of single-step exclusion of dependent variables.

Study limitations. Limitations of the study result from the cross-sectional design and data based on self-reporting.

\section{Results}

Cluster analysis revealed two relatively homogenous groups of the adolescents in the sample: one with a low degree of readiness for vandalism (90\%). and one with a high degree of readiness for vandalism (10\%). Clustering convergence equaled 0.7 (likelihood function - log-likelihood, Bayesian information criterion (BIC)).

Table 1

Distribution of participants according to the family types

\begin{tabular}{|c|c|c|c|c|}
\hline \multirow{2}{*}{\multicolumn{2}{|c|}{ Families }} & \multicolumn{2}{|c|}{ Adolescents } & \multirow{2}{*}{ Total F (\%) } \\
\hline & & Boys F (\%) & Girls F (\%) & \\
\hline \multirow{2}{*}{$\begin{array}{l}\text { Well-to-do } \\
\text { families }\end{array}$} & two-parent families & $9(15)$ & $10(17)$ & $19(32)$ \\
\hline & one-parent families & $13(22)$ & $3(5)$ & $16(27)$ \\
\hline \multirow{2}{*}{$\begin{array}{l}\text { Disadvantaged } \\
\text { families }\end{array}$} & two-parent families & $2(3)$ & $4(7)$ & $6(10)$ \\
\hline & one-parent families & $14(23)$ & $5(8)$ & $19(31)$ \\
\hline & Total: & $38(63)$ & $22(37)$ & $60(100)$ \\
\hline
\end{tabular}

Applying the method of contingency tables, we investigated relationships between the main criteria (in pairs): the number of parents in a family; the family's social wellbeing or not, and the adolescents' propensity for vandalism or not. The results ( See Table 2) showed that adolescents with high propensity for vandalism come more often from disadvantaged families $(\mathrm{V}=0.649 ; \mathrm{p}=0.000)$. Further processing of the sample data revealed that one-parent families appear to be disadvantaged more often (Cramer's V criterion $=0.303 ; \mathrm{p}=0.019$ and $\chi^{2}=5.503$; $\mathrm{p}=0.033$ ).

Based on the MANOVA analysis, we can assume that adolescents from the disadvantaged families tend to be more prone to vandalism. Indicators of adolescents' total propensity for vandalism are high mostly in two-parent disadvantaged families. Adolescents from well-to-do families (both one- and two-parent families) are not characterized by high total propensity for vandalism. Herewith, further investigation of vandalism predictors used only the grouping indicator of social wellbeing as the determinative one. In our sample we have $59 \%$ of adolescents from well-todo families and $41 \%$ from disadvantaged families. 
Table 2

Correlations between motives for adolescent vandalism and family type classified by the number of parents and their social wellbeing (MANOVA)

\begin{tabular}{lccccc}
\hline & & \multicolumn{5}{c}{ Mean } \\
\cline { 3 - 6 } $\begin{array}{l}\text { Dependent } \\
\text { variables }\end{array}$ & $\mathrm{R}^{2}$ & $\begin{array}{c}\text { One-parent } \\
\text { well-to-do } \\
\text { families }\end{array}$ & $\begin{array}{c}\text { One-parent } \\
\text { disadvantaged } \\
\text { families }\end{array}$ & $\begin{array}{c}\text { One-parent } \\
\text { well-to-do } \\
\text { families }\end{array}$ & $\begin{array}{c}\text { Two-parent } \\
\text { disadvantaged } \\
\text { families }\end{array}$ \\
\hline Grabbing & $.53^{* * *}$ & 9.25 & 11.80 & 8.79 & 18.83 \\
Aggressive & $.43^{* * *}$ & 8.88 & 11.53 & 8.37 & 14.50 \\
Tactical & $.48^{* * *}$ & 8.38 & 9.79 & 8.16 & 12.50 \\
$\begin{array}{l}\text { Being curious } \\
\text { Aesthetic }\end{array}$ & $.15^{*}$ & 8.13 & 8.95 & 8.00 & 8.00 \\
$\begin{array}{l}\text { Existential } \\
\text { Protesting }\end{array}$ & $.37^{* * *}$ & 9.94 & 14.26 & 8.63 & 14.83 \\
$\begin{array}{l}\text { Conforming } \\
\text { Provoked by } \\
\text { environmental } \\
\text { discomfort }\end{array}$ & $.83^{* * *}$ & 8.19 & 9.37 & 8.00 & 11.00 \\
$\begin{array}{l}\text { Provoked by } \\
\text { boredom }\end{array}$ & $.42^{* * *}$ & 8.31 & 8.42 & 8.00 & 15.00 \\
$\begin{array}{l}\text { Propensity for } \\
\text { vandalism, total }\end{array}$ & $.64^{* * *}$ & 8.81 & 9.74 & 8.21 & 12.00 \\
\hline
\end{tabular}

Note. $R^{2}=$ Squared multiple correlation; ${ }^{*}=p<.05 ;{ }^{* *}=p<.01 ;{ }^{* * *}=p<.001$

Table 3 contains only statistically significant models. These regression models reveal possible predictors of adolescent vandalism in the sphere of parent-child relationships. We can emphasize that in well-to-do families we discovered statistically significant models for all types of data. We did not find statistically significant correlations between indicators of adolescent perception of father's style of upbringing and abnormalities in the father's style of parental upbringing in either well-to-do and disadvantaged families.

We can suppose that the regression models in Table 3 have a high level of predictive value as they have explained a variation of more than $50 \%$ in the sample data set. This indicator also points out the significance of family upbringing style in forming adolescents' propensity for vandalism.

\section{Discussion}

\section{Motives and general propensity for vandalism}

1. Adolescents from two-parent disadvantaged families. Results of the statistical analysis showed greater propensity for vandalism in this group. Adolescents have mainly grabbing motives for their vandalism. They use vandalism as a destructive 
Table 3

Predictors of adolescents' propensity for vandalism in the sphere of parental upbringing. The results of linear regression analysis

\begin{tabular}{|c|c|c|c|c|}
\hline & & $\mathbf{R}^{2}$ & Independent variables & $\beta$ \\
\hline \multirow{15}{*}{ 离 } & \multirow{8}{*}{$\begin{array}{l}\text { Abnormalities in the } \\
\text { style of parental up- } \\
\text { bringing }\end{array}$} & \multicolumn{2}{|c|}{ Disadvantaged families } & \\
\hline & & \multirow[t]{7}{*}{$.92^{* * *}$} & Hypoprotection & $-.76^{\star *}$ \\
\hline & & & Indulgence & $-.82^{\star}$ \\
\hline & & & Ignoring child's needs & $.84^{\star * *}$ \\
\hline & & & Excessive requirements-prohibitions & $1.35^{* * *}$ \\
\hline & & & Lack of duties & $-.67^{* * *}$ \\
\hline & & & Excessive sanctions & $.59^{*}$ \\
\hline & & & Inconsistency of parental upbringing style & $-1.95^{\star * *}$ \\
\hline & \multirow{7}{*}{$\begin{array}{l}\text { Psychological reasons } \\
\text { of abnormalities in } \\
\text { parental upbringing }\end{array}$} & \multirow[t]{7}{*}{$.91^{\star * *}$} & Expansion of parental feelings' sphere & $-3.36^{* * *}$ \\
\hline & & & Preference for childish traits & $-1.40^{* * *}$ \\
\hline & & & Lack of parental confidence & $-1.46^{* * *}$ \\
\hline & & & Undeveloped parental feelings & $-2.57^{\star * *}$ \\
\hline & & & $\begin{array}{l}\text { Projection of own objectionable traits onto } \\
\text { a child }\end{array}$ & $4.22^{* * *}$ \\
\hline & & & Preference for feminine traits & $7.28^{* * *}$ \\
\hline & & & Preference for masculine traits & $5.26^{* * *}$ \\
\hline 离 & $\begin{array}{l}\text { Abnormalities in the } \\
\text { style of parental up- } \\
\text { bringing }\end{array}$ & $.80^{\star}$ & Hypoprotection & $.89^{*}$ \\
\hline \multirow{2}{*}{ 它 } & \multirow{2}{*}{$\begin{array}{l}\text { Perception of mother's } \\
\text { style of upbringing }\end{array}$} & \multirow[t]{2}{*}{$.46^{* *}$} & Positive interest & $1.37^{* * *}$ \\
\hline & & & Autonomy & $-1.19^{\star *}$ \\
\hline
\end{tabular}

Well-to-do families

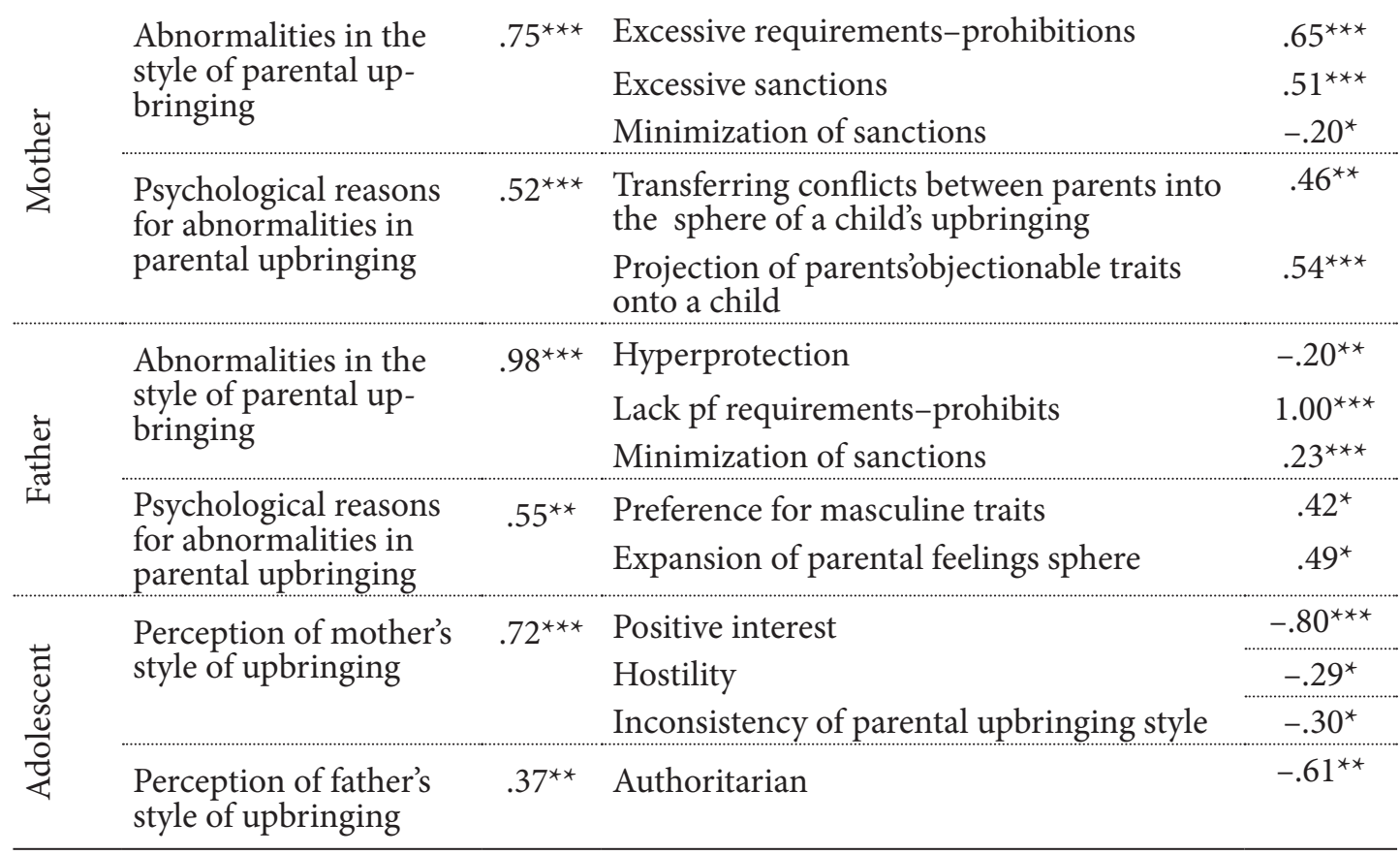

Note. $R^{2}=$ Squared multiple correlation; $\beta=$ Standardized regression coefficient; ${ }^{*}=p<.05 ;{ }^{* *}=p<.01$; $* * *=p<.001$ 
tactic for changing their environment and making it more comfortable for themselves, or for the purpose of aesthetic transformation of the environment. Destructive activity by adolescents from this type of family is also systematically initiated by protesting or aggressive reactions. Based on the analysis of motives, we can assume that in this group of adolescents, practically all presented types of motives except curiosity and boredom are common triggers for their vandalism. We should note that, of all the motives for vandalism, only curiosity and boredom are considered to be normative for adolescents, because they are part of socializing mechanisms for this age group (Vorobyeva \& Kruzhkova, 2014). The low extent of these (normative) motives in the overall motivation base of vandalism in the adolescents' sample may be evidence of these adolescents' conscious choice of deviant destructive relationships with their environment.

The finding that adolescents from two-parent disadvantaged families have the highest risk of vandalism allows us to conclude that the character of relationships between parents and style of family upbringing are more important than the number of parents in the family (Koneva, 2009). Investigations of the influence of these factors on adolescents' propensity for vandalism can be a subject for future research to complement this one.

2. Adolescents from one-parent disadvantaged families. In this group the indicator of general readiness for vandalism was also very high. The motives of the adolescents were mainly aesthetic: they wanted to make environment look nicer and more comfortable, according to their ideas about the environmental esthetic. The motives of aggression, protest, and environmental discomfort were more frequently expressed than all others. The prevalence of aesthetic motives for vandalism can be also explained by the popularity of such teenage subcultures as graffiti, street-art, and so on (Nordmarker, Hjärthag, Perrin-Wallqvist, \& Archer, 2016). We should also take into account the possibility of compensatory reaction: adolescents' desire to escape from the real life and create their own world with typically adolescent social relationships (Belkin, 2010; Haza \& Ducousso-Lacaze, 2006)

3. Adolescents from well-to-do families have minimal risk of committing vandalism. Parental attention to their children and constructive dialogue between them do not favor development of these adolescents' negative feelings, because at this age, adolescents' satisfaction with life has a strong positive correlation with the quality and ease of communication in the family (Hodačova, Čermakova, Šmejkalova, Hlavačkova, \& Kalman, 2015). Adolescents from well-to-do families have a low propensity for vandalism independently of the number of parents in the family. Average indicators of adolescents' propensity for vandalism in this group are less than 10 points. This average is a norm for this age, according to the norms referenced in the test "Motives of vandal behavior" (Vorobyeva \& Kruzhkova, 2015).

4. Hence, abusive relationships in the family represent a significant factor forming an adolescent's propensity for vandalism. This finding strengthens the ideas of other authors that an ineffective style of parenting is the main factor causing abnormal socialization of adolescents (Lelekov \& Kosheleva, 2006; Istratova, 2013). At the same time, family wellbeing allows parents to choose a more effective 
general parental style of upbringing that gives an adolescent more opportunities to form constructive behavior and achieve social wellbeing (Steca, Bassi, Caprara \& Fave, 2011).

\section{Predictors of adolescents' propensity for vandalism in the sphere of parental upbringing}

1. Disadvantaged families. Based on the results of the regression analysis, we can conclude that in disadvantaged families, adolescents' propensity for vandalism is formed under the influence of the mother's excessive requirements, sanctions, and ignorance of their needs. Our assumption is that a mother's attention to her children, even with lots of resources and personal efforts spent on the child's upbringing, may have no positive effect if the child's interests are not taken into consideration. In this situation an adolescent is overloaded with an excessive list of duties whose performance is always controlled by his/her parents, and sanctions are never eased. Z. Wajda notes that a mother's strict control can lead to child's aggressive behavior (Wajda, 2013).

Our analysis of the psychological reasons for the abnormalities in the parental upbringing in this group revealed two most probable reasons for such a mother's attitude toward the adolescent and her choice of the destructive style of parental upbringing. They are a projection of her own objectionable traits onto the child, and a stable system of stereotypes about feminine and masculine traits. In addition, mothers from this group tend to be convinced of the rightness of their parental efforts. Also these mothers often perceive adolescents as adults and unconsciously force them to be independent and self-reliant, thus developing guilt complexes, hyper-responsibility, and feelings of inferiority in the adolescents. These mothers demonstrate their own dominant position, and refuse to listen to the adolescents and understand their needs, consciously distancing themselves from children, and demanding submission.

In disadvantaged families, the father plays a minimal role in parental upbringing, has little interest in the child's development, and only participates in the child's upbringing formally or on request. This explication accords with the previous research results of S.L. Sibirjakov, who investigated adolescents with deviant behavior, and found the main reasons of such behavior in the family sphere to be the absence of emotional contact with both parents or one of them, and a low level of mutual understanding and collaboration between parents (Sibirjakov, 1998).

Nevertheless, an adolescent from a disadvantaged family perceives his/her mother's upbringing efforts rather positively. In spite of this, the lack of parental interest in the adolescent and the lack of the adolescent's autonomy create the adolescent's readiness to participate in vandalism. We hypothesize that an adolescent's propensity for vandalism in this case relates to his/her childhood relationships with his/her parents - i.e., when a child attracts parental attention by means of disobedience and other negative behavior patterns (Dittman, Farruggia, Keown, \& Sanders, 2016; Bogdanova, Rusyaeva \& Vylegzhanina, 2016). Regression analysis did not show any significant correlation between an adolescent's attitude toward his/her father's upbringing style, and the adolescent's propensity for vandalism; this can be a consequence of the father's insignificant participation in the adolescent's life. 
2. Well-to-do families. Isolated cases of adolescent vandalism within this group have some significantly different predictors in the family sphere. A mother can provoke an adolescent into destructive actions by increasing requirements, limiting his (her) freedom and independence. At the same time there may be too strict punishment for any faults, even those which are rare and insignificant. The reasons for a mother's domination and her strict style of parental upbringing can flow from transferring her conflict with her husband to the sphere of motherchild relationship, and also projecting her own undesirable traits onto a child. As a result, irregular adolescent vandalism may have the function of releasing negative emotions and expressing aggression toward items seen as substitutes for the mother herself (for example, home and mother's personal items, home appliances, furniture, and etc.). A father may provoke an adolescent's vandalism by his noninterference in the upbringing process, a non-interference which may be based on the father's attitude that the adolescent is an adult and responsible person. The father can perceive an adolescent as a friend and partner in common interests, and also a rival struggling for the attention of his wife, and as a stranger who lives own life.

An adolescent from a well-to-do family perceives his/her mother's inconsistent style of parental upbringing as a provocation for destructive activities. The unpredictability of her emotional reactions and actions, and the ambiguity of situations followed by punishments and encouragements, lead to the tense expectations of what she will do. Adolescents in this situation consider the lack of the father's active involvement as a factor enabling his/her own destructive behavior.

Hence maternal and paternal upbringing style have different effects on adolescents' behavior both in disadvantaged and well-to-do families, a result which accords with the research of E. Gracia and colleagues (Gracia, Lila, \& Musitu, 2005). In any case, emotional contact between parents and adolescent, and a good (not-conflictive) relationships of the adolescent with his/her parents allows for a decreased risk of adolescent vandalism behavior in general, and especially of vandalism based on aggressive reactions (Csémy, Hrachovinová, Čáp, \& Starostová, 2014).

\section{Conclusion}

The results of our research prove a significant correlation between an adolescent's propensity for vandalism and violence, and an unfriendly atmosphere in the family. This correlates with the results of earlier investigations of adolescents with deviant behavior (Sibirjakov, 1998; Csémy, Hrachovinová, Čáp, \& Starostová, 2014). In addition, our analysis of the styles of parental upbringing as predictors of adolescents' propensity for vandalism further clarifies which types of maternal and paternal behavior and relationships with a child favor an adolescent's propensity for vandalism.

This research supports the thesis that strict control by others can lead to a child's aggressive behavior (Wajda, 2013), but it also reveals the difference between problem-free and disadvantaged families on this issue. An adolescent from a disadvantaged family perceives the mother's upbringing efforts quite positively. 
Our results prove a significant correlation between an adolescent's propensity for vandalism and an atmosphere of violence in the family. The number of parents in the family is an insignificant factor in forming and internalizing adolescent vandalism. The main predictors of adolescent propensity for vandalism can be found in the styles of parental upbringing. Herewith, we should consider that paternal and maternal styles of upbringing have different specific effects for developing adolescents' propensity for vandalism, a result which accords with the research results of Gracia, Lila, \& Musitu (2005). Maternal upbringing has the greatest influence on adolescent destructive behavior, especially when the father's upbringing style is non-interference.

These findings should start a discussion about the necessity of transferring the focus of preventive measures against vandalism from the adolescent alone to his/ her whole family. We also propose that preventive efforts against vandalism be directed to prevention of family violence, as well to taking a differential approach to parental education, directed to correction of individual parental styles of upbringing. Implementing these recommended changes in the strategy of vandalism prevention will lead to decreasing adolescents' propensity not only for vandalism, but for all forms of deviant behavior.

\section{Acknowledgments}

This paper is based on research carried out with the financial support of a grant from the Russian Science Foundation (project №17-18-01278).

\section{References}

Agapov, A.F. \& Malkov, V.D. (2006). Crimonologia [Criminology]. Moscow: Justicinform [In Russian].

Avdulova,T.P. (2013). Socializacija rebenka v prostranstve sem'I [Socialisation of a child in a family space]. Psihologicheskie issledovanija - Psychological researches, 6(31), 9 [In Russian].

Belkin, A.I. (2010). Issledovanie osobennostej psihologicheskogo oposredovanija graffiti v subkul'turnom kontekste molodezhnoj i kriminal'noj subkul'tur [Investigation of specifics of psychological mediation by graffiti in subcultural context of youth and criminal cultures]. Prikladnaja juridicheskaja psihologija [Applied juridical psychology] 1, 85-97.

Bogdanova, M.V. \& Igoshina, N.S. (2011). Rol' materi v formirovanii psihologicheskih zashhit u chasto i dlitel'no bolejushhih detej [Role of a mother in forming psychological defenses of ailing children]. Vestnik Tjumenskogo gosudarstvennogo universiteta. Gumanitarnye issledovanija - Gerald of Tyumen State University. Humanitates 9, 232-240 [In Russian].

Bogdanova, M.V., Rusyaeva, I.A., \& Vylegzhanina, A.O. (2016). Gender and age aspects of child psychological defenses in child-mother relationships. Psychology in Russia: State of the Art 9(3), 141-158. https://doi.org/10.11621/pir.2016.0310

Csémy, L., Hrachovinová, T., Čáp, P., \& Starostová, O. (2014). Agresivní chování dospívajících: prevalence a analýza vlivu faktorů z oblasti rodiny, vrstevnických vztahů a školy [Aggressive adolescent behavior: popularity and family factors analysis, social relationships and school]. Československá psychologie - Czechoslovak psychology 58(3), 242-253 [In Czech].

De Haan, A.D., Prinzie, P., \& Deković, M. (2012). Change and reciprocity in adolescent aggressive and rule-breaking behaviors and parental support and dysfunctional discipline. Development and Psychopathology 24(1), 301-315. https://doi.org/10.1017/S0954579411000848 
Dittman, C.K., Farruggia, S.P., Keown, L.J., \& Sanders, M.R. (2016). Dealing with Disobedience: An Evaluation of a Brief Parenting Intervention for Young Children Showing Noncompliant Behavior Problems. Child Psychiatry and Human Development 47(1), 102-112. https://doi. org/10.1007/s10578-015-0548-9

Eydemiller, G. \& Yustitskis, V.V. (1999) Psihologiya i psihoterapiya semi [Family psychology and psychotherapy]. Sankt-Petersburg, Piter [In Russian].

Ellaway, A., Morris, G., Curtice, J., Robertson, C., Allardice, G., \& Robertson, R. (2011). Associations between health and different types of environmental incivility: A Scotland-wide study. Public Health, 123(11), 708-713. https://doi.org/10.1016/j.puhe.2009.09.019

Elliott, D. (1988). Multiple problem youth. New York: Springer-Verlag.

Federal'nyj zakon ot 24 ijunja 1999 g. N 120-FZ "Ob osnovah sistemy profilaktiki beznadzornosti i pravonarushenij nesovershennoletnih» [Federal law from 24/06/1999 N 120-FZ "On basic prevention system of neglect and juvenile delinquency"]. (n.d.). Retrieved from http:// base.garant.ru/12116087/1/\#block_100\#ixzz4aBUQ5t19 [In Russian].

Garbarino, J., Sebes, J., \& Schellenbach, C. (1984). Families at risk for destructive parent-child relations in adolescence. Child development 55(1), 174-183. https://doi.org/10.2307/1129843

Goldstein, A. (1996). The psychology of vandalism. New York: Plenum Press.

Gracia, E., Lila, M., \& Musitu, G. (2005). Parental rejection and psychosocial adjustment of children. Salud Mental 28(2), 73-81.

Haza, M. \& Ducousso-Lacaze, A. (2006). Marquage du corps et marquage du mobilier urbain : Expressions de la problématique adolescente [Markings on the body and markings on street furniture: expressions of the adolescent problem]. Cahiers de Psychologie Clinique - Clinical Psychology workbooks, 26(1), 163-175. https://doi.org/10.3917/cpc.026.0163

Hodačova, L., Čermakova, E., Šmejkalova, J., Hlavačkova, E., \& Kalman, M. (2015) Vztah rodiny a životní spokojenosti dětí [The relation of family and life satisfaction of Czech children]. Československa psychologie - Czechoslovak psychology 59(4), 315-326 [In Czech].

Istratova, O.N. (2013). Semejnoe neblagopoluchie kak social'no-psihologicheskaja problema [Family unhappiness as social-psychological problem]. Izvestija Juzhnogo federal'nogo universiteta. Tehnicheskie nauki - News of South Federal University. Technical sciences 10, 242249 [In Russian].

Koneva, O.B. (2009). Neblagopoluchnaja sem'ja i deviantnoe povedenie: social'no-psihologicheskie priznaki [Unhappy family and deviant behavior: social-psychological indicators]. Vestnik Cheljabinskogo gosudarstvennogo universiteta - Gerald of Chelyabinsk State University 14 (152), 44-50 [In Russian].

Koreneva, A.A. (2004) Vzaimosvjaz' semejnogo vospitanija i agressivnosti v podrostkovom vozraste [Relationships between family upbringing and adolescent aggressiveness]. Extended abstract of Doctor's thesis. Moscow [in Russian].

Kuznecova, V.B. (2013) Chuvstvitel'nost' k podkrepleniju kak faktor psihologicheskogo zdorov'ja detej i podrostkov [Sensitivity to reinforcement as a factor of child and adolescent mental health]: Extended abstract of candidate's thesis. Moscow [in Russian].

Le Blanc, M. \& Freshette, M. (1989). Male criminal activity from childhood through youth. New York: Springer-Verlag. https://doi.org/10.1007/978-1-4612-3570-5

Lelekov, V.A. \& Kosheleva, E.V. (2006). Vlijanie sem'i na prestupnost' nesovershennoletnih [Family influence on juvenile delinquency]. Sociologicheskie issledovanija - Sociological researches 1, 103 [In Russian].

Levy-Leboyer, C. (1984). Vandalism: Behavior and motivation. Amsterdam: Elsevier science publishers.

Lucia, S. \& Killas, M. (2011). Is animal cruelty a marker of interpersonal violence and delinquency? Results of a Swiss national self-report study. Psychology of Violence 1(2), 93-105. https://doi.org/10.1037/a0022986 
Mawby, R.I. (2001). Burglary. Devon, UK: Willan Publishing.

Networkrail. Graffiti. (2017). Find out how we tackle graffiti on the railway and what you can do to report it. Retrieved 03/12/2017 from http://www.networkrail.co.uk/aspx/1022.aspx.

Nordmarker, A., Hjärthag, F., Perrin-Wallqvist, R., \& Archer, T. (2016). The roles of gender and personality factors in vandalism and scrawl-graffiti among Swedish adolescents. PsyCh Journal 5(3), 180-190. https://doi.org/10.1002/pchj.133

Parliament of New South Wales Legislative Assembly (2009). First Session of the Fifty-Fourth Parliament: Questions and Answers No. 108. 22 January 2009. (n.d.). Retrieved from https:// www.parliament.nsw.gov.au/la/papers/Documents/2009/22-january-2009-questions-andanswers/108-QA-S.pdf

Rohner, R.P. (1984) Handbook for the Study of Parental Acceptance and Rejection. Connecticut: University of Connecticut.

Schaefer, Earl S. (1965) A configurational analysis of children's reports of parent behavior. Journal of Consulting Psychology 29(6), 552-557. https://doi.org/10.1037/h0022702

Shvedovskaya, A.A. \& Archakova, T.O. (2015). Styles of parent-child interactions in families with preschool-age children. Psychology in Russia: State of the Art, 8(2), 36 -51. https://doi. org/10.11621/pir.2015.0204

Sibirjakov, S.L (1998). Preduprezhdenie deviantnogo povedenija molodezhi (metodologicheskie i prikladnye problemy) [Prevention of deviant youth behavior (methodological and practical problems]. Volgograd: Volgogradskij juridicheskij institut VJuI MVD Rossii [In Russian].

Simonova, I.A. (2010). Rekursivnyj potencial subkul'turnyh soobshhestv: tipologija social'nogo processa [Recursive potential of subcultural societies: typology of the social process]. Vestnik Cheljabinskogo gosudarstvennogo universiteta - Gerald of Chelyabinsk State University 31, 53-60 [In Russian].

Steca, P., Bassi, M., Caprara, G.V., \& Fave, A.D. (2011). Parents' self-efficacy beliefs and their children's psychosocial adaptation during adolescence. Journal of Youth and Adolescence 40(3), 320-331. https://doi.org/10.1007/s10964-010-9514-9

Thompson, K., Offler N., Hirsch, L., Every, D., Thomas, M.J., \& Dawson, D. (2012). From broken windows to a renovated research agenda: A review of the literature on vandalism and graffiti in the rail industry. Transportation Research Part A 46, 1280-1290. https://doi.org/10.1016/j. tra.2012.04.002

Uniform Crime Report. (2013). Crime in the United States, Arrests, by Race, 2013. Table 43A, 43B, 43C. US: U.S. Department of Justice. Federal Bureau of Investigation. Retrieved 03/12/2017 from https://ucr.fbi.gov/crime-in-the-u.s/2013/crime-in-the-u.s.-2013/tables/ table-43/tab43overview_final.pdf.

Vasserman, L.I., Gor'kovaja, I.A., \& Romicyna, E.E. (2001). Psihologicheskaja metodika «Podrostki o roditeljah» i ee prakticheskoe primenenie [Psychological methodic "Adolescents about parents" and its practical application]. Sankt-Petersburg: Farmindex [In Russian].

Vasserman, L.I., Gor'kovaja, I.A., \& Romicyna, E.E. (2000). Metodika "Podrostki o roditeljah" (ADOR): osnovnye jetapy aprobacii russkojazychnoj versii [Methodic "Adolescents about parents": main steps of approbation of its Russian version]. Psihologicheskij zhurnal - Psychological journal 21(5), 86-95 [In Russian].

Vatova, L.S. (2007). Socialno-psihologicheskoe osnovanie molodezgnogo vandalizma i ego profilaktika [Social-psychological bases of youth vandalism and its prevention]. Moscow: Narodnoe obrazovanie [In Russian].

Virtanen, P., Nummi, T., Lintonen, T., Westerlund, H., Hägglöf, B., \& Hammarström, A. (2015). Mental health in adolescence as a determinant of alcohol consumption trajectories in the 
Northen Swedish Cohort. International Journal of Public Health 60(3), 335-342. https://doi. org/10.1007/s00038-015-0651-5

Vorobyeva, I.V., Kruzhkova, O.V., \& Krivoshchekova, M.S. (2015). The genesis of vandalism: From childhood to adolescence. Psychology in Russia: State of the Art 8(1), 139-156. https:// doi.org/10.11621/pir.2015.0112

Vorobyeva, I.V. \& Kruzhkova, O.V. (2011) Vozmozhnosti diagnostiki motivov vandal'nogo povedenija [Opportunities of diagnostics of motives of vandalism behavior]. Bulletin of South Ural State University 42, 35-40 [In Russian].

Vorobyeva, I.V. \& Kruzhkova, O.V. (2014) Vandalizm kak sredstvo samopoznanija v junosheskom vozraste [Vandalism as a means of self-knowledge in the adolescence]. Abstracts: Shestaja Mezhdunarodnaja konferencija po kognitivnoj nauke (23-27 ijunja 2014 goda) - VI International conference on cognitive science. (pp. 207-208). Kaliningrad [In Russian].

Vorobyeva, I.V. \& Kruzhkova, O.V. (2015). Psihologija vandal'nogo povedenija: monografija [Psychology of vandal behavior: monograph]. Ekaterinburg: UrGPU [In Russian].

Wajda, Z. (2013). The perception of the relationship between parents, patterns of attachment, and psychopathological symptoms in girls in late adolescence. Psychiatria Polska 47, 5, 853864.

Wilson, J.Q. \& Kelling, G.L. (2013). Broken windows. Manhattan Institute for Policy Research, Retrieved from http://www.manhattan-institute.org/pdf/_atlantic_monthly-broken_windovs.pdf 